\title{
Geologic Reconnaissance of Frosty Peak Volcano \\ and Vicinity, Alaska
}

By HOWARD H. WALDRON

INVESTIGATIONS OF ALASKAN VOLCANOES

* GEOLOGICALSURVEY B ULLETIN $1028-\mathrm{T}$

Prepared in cooperation with the Office,

Chief of Engineers, U.S. Army

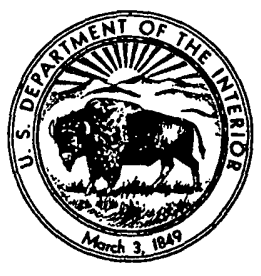


UNITED STATES DEPARTMENT OF THE INTERIOR

STEWART L. UDALL, Secretary

4

\section{GEOLOGICAL SURVEY}

Thomas B. Nolan, Director 


\section{PREFACE}

In October 1945 the War Department (now Department of the Army) requested the Geological Survey to undertake a program of volcano investigations in the Aleutian Islands-Alaska Peninsula area. The first field studies, under general direction of G. D. Robinson, were begun as soon as weather permitted in the spring of 1946. The results of the first year's field, laboratory, and library work were assembled hastily as two administrative reports. Part of the data was published in 1950 in Geological Survey Bulletin 974-B, "Volcanic Activity in the Aleutian Arc," by Robert R. Coats. The remainder of the data have been revised for publication in Bulletin 1028 .

The investigations of 1946 were supported almost entirely by the Mulitary Intelligence Division of the Office, Chief of Engineers, U.S. Army. The Geological Survey is indebted to the Office, Chief of Engineers, for its early recognition of the value of geologic studies in the Aleutian region, which made this report possible, and for its continuing support. 


\section{CONTENTS}

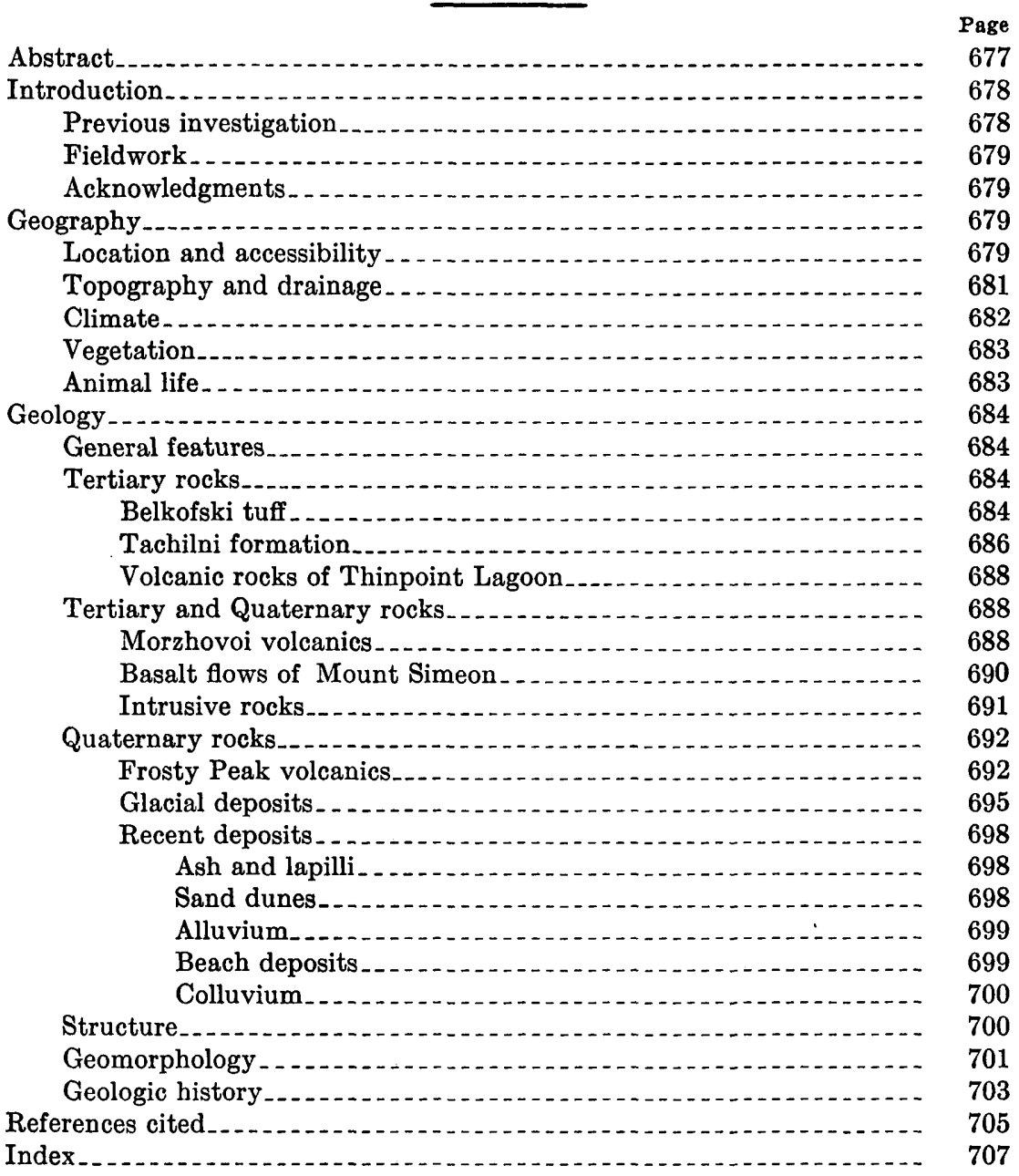

\section{ILLUSTRATIONS}

Plate 79. Geologic reconnaissance map and section of Frosty Peak volcano and vicinity ........................... In pocket

Figure 104. Map of Alaska Peninsula and Aleutian Islands........ 680 



\title{
INVESTIGATIONS OF ALASKAN VOLCANOES
}

\section{GEOLOGIG RECONNAISSANGE OF FROSTY PEAK VOLCANO AND VICINITY, ALASKA}

\author{
By Howard H. Waldron
}

\begin{abstract}
Frosty Peak is a nested summit cone of a prominent Quaternary volcano on the western end of the Alaska Peninsula, between Cold Bay on the east and Morzhovoi Bay on the west. This part of the peninsula comprises two major physiographic provinces-a deeply glaciated and eroded mountainous area bordering the Pacific Ocean and a tundra-covered coastal lowland border-
\end{abstract} ing the Bering Sea.

The oldest rock unit recognized in the area is the Belkofski tuff, a thick sequence of well-bedded volcanic sedimentary rocks, tuff, agglomerate, and some interbedded flows, principally of basaltic composition, that crop out along the Pacific coast east of Cold Bay. The rocks have been moderately deformed and intruded by quartz diorite stocks and by dikes, sills, and plugs of basalt and andesite. These rocks have been deeply eroded and are believed to be middle Tertiary in age. A sequence of poorly consolidated and slightly deformed marine sedimentary rocks, here named the Tachilni formation, which are probably derived from the Belkofski tuff and associated intrusive rocks, crop out along the Pacific coast west of Cold Bay. The age of these rocks is believed to be late Tertiary. Volcanic rocks in isolated knobs and hills in the vicinity of Thinpoint Lagoon are of unknown age, but are also believed to be Tertiary.

In very late Tertiary or early Quaternary time, volcanic activity southeast of Morzhovoi Bay built up a large stratovolcano, here called Morzhovoi volcano, on the eroded remnants of the older rocks. The rocks of this ancient volcano are light-gray porphyritic olivine basaltic lava flows and interbedded pyroclastic rocks, and some reworked volcanic material, and are here named the Morzhovoi volcanics. Eruption of this volcano, in early to middle Pleistocene, culminated in collapse of the central part, leaving a great caldera. Later, a large double-coned volcano, here called Frosty volcano, was built up on the northern flanks of the eroded remains of Morzhovoi volcano. Frosty volcano was partly destroyed by caldera-forming activity, and subsequent renewal of eruption built a prominent volcanic cone, Frosty Peak cone, in the southern part of the caldera. The rocks of the ancestral Frosty volcano and of the younger Frosty Peak cone are basaltic lava flows and some associated pyroclastic rocks, here named the Frosty Peak volcanics. Since the last eruptions at Frosty Peak, probably very late in Pleistocene or in Recent time, glaciers, streams, and frost action have been rapidly dissecting its upper slope.

The area was glaciated extensively during the Pleistocene. Glaciers drain- 
ing to the north formed large piedmont glaciers, from which was deposited thick drift on the lowlands; glaciers draining to the south, however, calved off directly into the Pacific Ocean, and left little or no glacial drift along the Pacific coast. A large icefield, now occupying the northern part of the caldera of old Frosty volcano, spills over low cols in the caldera rim and pushes a large tongue of ice down toward Morzhovoi Bay.

\section{INTRODUCTION}

Frosty Peak, a prominent Quaternary volcano on the western end of the Alaska Peninsula (fig. 104), is one of more than 75 major volcanoes known in the Aleutian volcanic arc (Coats, 1950). This great arc, which is dominated nearly throughout by volcanoes and the products derived from them, extends for more than 1,500 miles southwestward and westward from the Alaskan mainland, and is one of the earth's major structural features in the north Pacific Ocean. The potential threat of destruction by these volcanoes to major military and civil installations in the area, led to a request by the War Department, in 1945, for the Geological Survey to undertake a program of volcano research in the Aleutian arc. The investigation of Frosty Peak and surrounding area, as described in this report, is a part of the program of research designed by the Geological Survey to provide basic information on the general geology of the Aleutian arc, and on its past and probable future volcanic activity with respect to the various military and civilian establishments.

\section{PREVIOUS INVESTIGATION}

Very little geographic or geologic investigation has been done on the western end of the Alaska Peninsula. Although the Alaska. Peninsula was discovered and visited by Russian and English explorers as early as 1741 (Baker, 1906), the first significant examination of the peninsula was not made until the summer of 1828 , when Capt. M. N. Staniukovich surveyed the north shore of the Alaska Peninsula. Lieutenant Woronkofski surveyed the southern shore of the peninsula in 1836. Ilia G. Wosnenski collected minerals and fossils from the peninsula in 1842-43 for the Imperial Academy of. Science of St. Petersburg. In 1848, Grewingk (1850) compiled a summary of all previous work of a geographic and geologic nature and assembled the facts in a single convenient volume. Dall (1896, p. 842-847) briefly discussed areas reported to contain upper Miocene fossiliferous marine strata on the western end of the peninsula. Atwood (1911) mapped parts of the Alaska Peninsula, including the Balboa-Herendeen Bay and Unga Island regions, in 1908. Jaggar $(1929,1945)$ visited the area in 1927 and 1928 while making a reconnaissance investigation of the Alaska Peninsula and Aleutian 
Islands, but the scientific results of his investigations were not published. Capps (1934) briefly examined some coastal parts of the area in 1932. Hubbard (1935) visited the area in 1934. Kennedy and Waldron (1955) mapped the geology of Pavlof Volcano and vicinity, immediately east of the Frosty Peak area, in 1946. A very interesting and useful summary account of the people and natural history of the Aleutian Islands and Alaska Peninsula, including keys for the identification of birds and plants of the area, was prepared by the Smithsonian Institution as a War Background Study (Collins and others, 1945).

\section{FIELDWORK}

The fieldwork on which this report is based was done by the writer, assisted by D. R. Nichols, during the summer of 1947. As no base maps were available at the time of the investigation, field data were compiled on trimetrogon aerial photographs. Subsequent to the field investigations, single-lens vertical aerial photographs of parts of the area were made available and examined. The base map (pl. 79) is a 1:100,000 composite of parts of the False Pass and Fort Randall 1:250,000 quadrangles.

The geologic information presented in this report is of reconnaissance nature. Accessibility of much of the area is difficult even under the most ideal conditions. During the 1947 field season the work was severely hampered by exceptionally stormy weather that prevailed throughout the summer and by the serious loss of a boat and other field equipment, including notes, cameras, and aerial photographs. Consequently, for some parts of the area, the data and interpretations presented here are based only on fragmentary information.

\section{ACKNOWLEDGMENTS}

Grateful acknowledgment is made of the friendly cooperation of the many officers and men stationed at the Thornborough Air Force Base at the time of the investigation, especially Majors F. J. Wesson, Jr., and E. S. Hinchliff, commanding officers; Capt. E. R. Hoover, ordnance officer, W. A. Brooks, post engineer, and Lt. D. B. Hartung, air installation officer. The cooperation and assistance given to the Survey party by the officials and employees of the Pacific American Fisheries, Inc., King Cove, are also gratefully acknowledged.

\section{GEOGRAPHY}

\section{LOCATION AND ACCESSIBILITY}

The area mapped geologically and called the Frosty Peak area in this report comprises a part of the western end of the Alaska Peninsula (fig. 104) that extends from the Bering Sea on the north to the $580554-61-2$ 


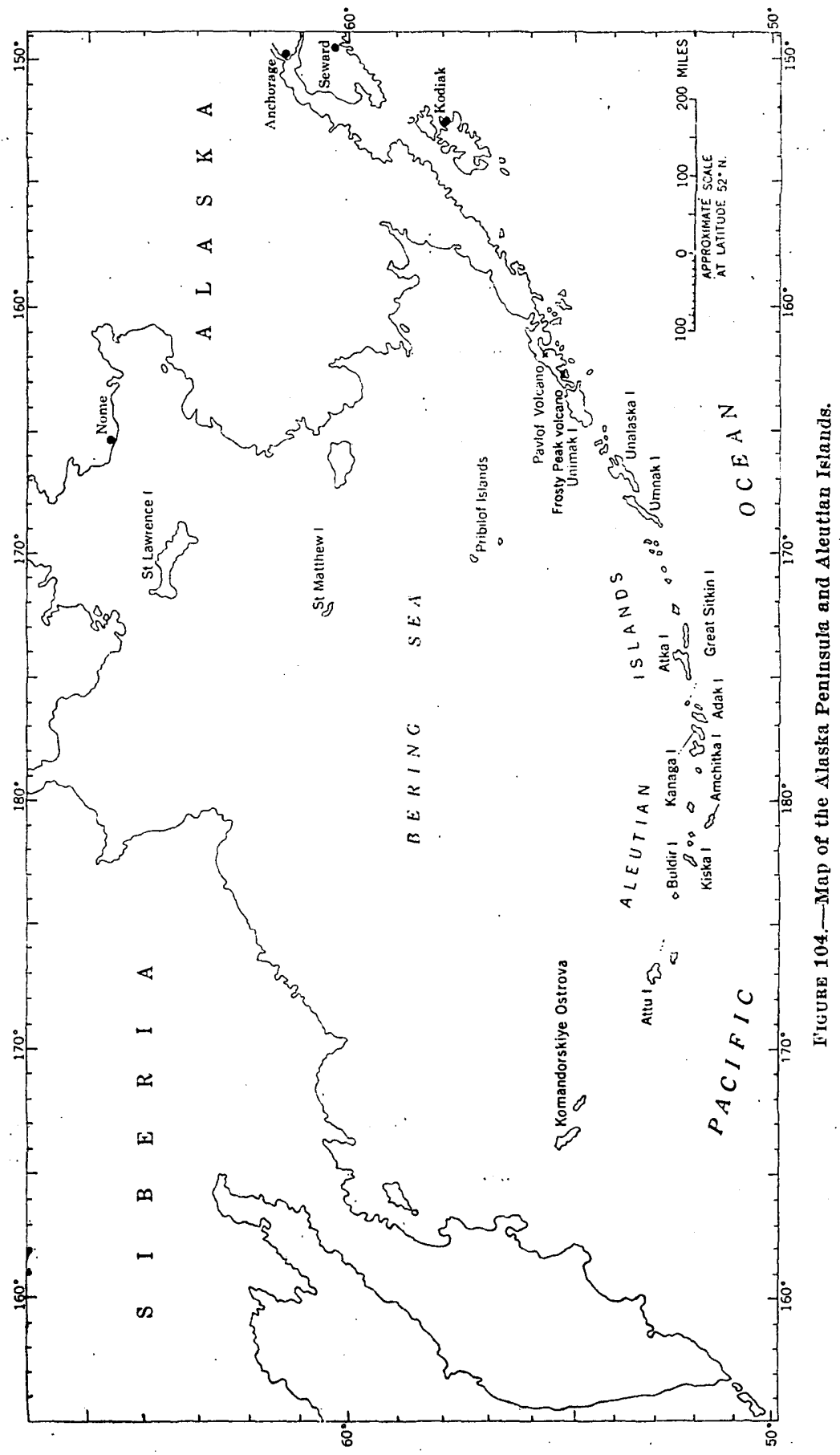


Pacific Ocean on the south and from Morzhovoi Bay on the west to the western shore of King Cove on the east. Cold Bay Airport, ${ }^{1}$ the only village in the mapped area, is on the northwest shores of Cold Bay, about 425 airline miles southwest of Kodiak and about 175 airline miles northeast of Dutch Harbor on Unalaska Island. King Cove, the site of a Pacific American Fisheries salmon cannery, lies at the eastern edge of the area mapped. Many trappers' huts and barabaras (native Aleut sod huts) are found throughout the area, principally along the shores of the bays and coves; they provide some emergency shelter and protection from storms.

At the time of the investigation, the area was accessible only by military air or sea transport and by scheduled airline flights of the Reeve Aleutian Airways, Inc., from Anchorage. Because there are no roads or manmade trails, except in the vicinity of the airbase, movement in most of the area is restricted to travel by foot or by water. Good anchorages are scarce, but small boats can obtain some shelter in the many lagoons and small bays.

\section{TOPOGRAPHY AND DRAINAGE}

The Alaska Peninsula, of which the Frosty Peak area is a part, consists of a chain of mountains known as the Aleutian Range. This range is bordered on the north by the extensive Bering Sea coastal lowland, and separated-in some places nearly isolated-by large northward-trending partly flooded lowlands. Several large islands and numerous islets and rocks lie offshore. In general the islands in the Pacific Ocean south of the peninsula are rugged and mountainous with rockbound and cliffed shores, whereas those to the north in the Bering Sea are low sandy bars.

The Aleutian Range in the Frosty Peak area is relatively low, averaging less than 1,000 feet in altitude. Large stratovolcanoes rise above the general level to an altitude of about 3,000 to 7,000 feet. The range has been deeply eroded by streams, glaciers, and frost action to produce many steep slopes, scarps, cliffs, and bare rock. Icefields and small glaciers occur on the higher peaks, especially on the north and northeast slopes. The mountains rise abruptly from the Pacific Ocean; steep-walled, fiordlike bays indent the rugged coastline, and with the exception of the lowlands partly encircling the larger bays, only a few broad, flat valleys interrupt the persistent cliffs and steep slopes. Narrow boulder beaches lie at the foot of the rocky cliffs, and sand beaches are found along the coastal lowlands and at the

\footnotetext{
2 Known as Fort Randall during World War II and in the early postwar years, and as Thornborough Air Force Base from about 1947 untll about 1954 or 1955 , and now operated by Civil Aeronautics Administration.
} 
heads of some bays and coves. Sand and gravel spits and bars are common in the bays and coves, whereas reefs and offshore rocks, abundantly fringed with kelp, commonly flank the rocky headlands.

The Bering Sea lowland constitutes a gently sloping plain that rises gradually from the sea to merge either imperceptibly with the mountain slopes, or in places, to intersect them sharply. The Bering Sea lowland is continuous throughout the area mapped, and is from less than 2 miles to more than 10 miles in width. The surface of this lowland is generally less than 200 feet above sea level; it is characterized by a dense growth of vegetation, many rounded hills, and numerous lakes, streams, and swamps. The shores are commonly sandy and backed by low bluffs cut into the grass-covered foredunes.

Rivers and streams abound in the area. Those draining into the Pacific Ocean generally flow in steep-walled valleys and are both shorter and of steeper gradient than those draining into the Bering Sea. The valleys are principally $U$-shaped glacial troughs with relatively flat floors; many of the streams head in glacial cirques. Permanent ice fills the coalescing craters of Frosty Peak volcano and spills over several low cols, where it forms either hanging glaciers or short cascading glaciers. The main ice drainage is westward into Morzhovoi Bay through a breach in the caldera rim north of the summit cone of Frosty Peak volcano. Here a large tongue of ice, heavily laden with rock debris, extends for nearly a mile downvalley.

\section{CLIMATE}

The Frosty Peak area is in one of the stormiest regions of the world. The frequent cyclonic storms crossing the North Pacific Ocean and the Bering Sea are the dominant factors influencing the weather of the area and account for the frequent occurrences of high winds, low clouds, and fog. The climate is basically maritime, and temperatures, though cold, are not normally severe, principally due to the moderating effect of warm water transported into the area by the Japan Current system. The mean annual temperature is about $37.5^{\circ} \mathrm{F}$, but the mean annual maximum and minimum temperatures differ less than $10^{\circ}$. Temperature extremes range from $78^{\circ}$ to $-9^{\circ} \mathrm{F}$, but temperatures below zero are extremely rare. Winter lasts 7 to 9 months, and frosts have been recorded for every month of the year except July and August.

The total precipitation is low, only about $33-34$ inches per year, but it is fairly evenly distributed throughout the year. Total snowfall also is low, averaging about $40-45$ inches, but it may accumulate to considerable thicknesses in drifts. Cloudiness averages about eight- 
tenths (80 percent) sky cover the year around; fog occurs most frequently during spring and summer months.

Winds of high velocities are common in the region; average monthly wind speeds of 20 miles per hour or more throughout the year are recorded at Cold Bay. In winter the winds are most frequently northwesterlies; in summer the prevailing winds are southsoutheast. Rapid variations in wind direction occur throughout the year, however, and strong winds of gale force may come from any direction during any time of the year. Williwaws, violent katabatic winds of local extent, frequently occur on the leeward side of the mountains. The williwaw is an especially dangerous wind for small boats, owing to the suddenness of its occurrence as well as to its violence and extreme gustiness.

\section{VEGETATION}

Arctic-type vegetation prevails in the area. The dominant and most conspicuous forms are the grasses, sedges, and mosses constituting the tundra plants that grow so profusely in the lowland areas and blanket the lower mountain slopes. Alder bushes and stunted willows, several varieties of shrubs and berry bushes, ferns, water plants, and many varieties of flowering plants also thrive on the lowland. Alder bushes generally are limited to the lower 400-500 feet of the mountain slopes and occur in irregularly scattered thickets on the lowlands. In places willows and alder bushes are as high as 20 feet, but generally they are only 4-6 feet high and grow as a maze of low, creeping branches. The upper limit of vegetation ranges from 1,000 to 1,500 feet in altitude.

\section{ANIMAL IIFE}

Animal life is abundant in the area. North America's largest omnivorous animal, the great brown bear, is both common and unpredictably dangerous enough that a traveler in the area must be armed and constantly alert. The caribou, which were once plentiful on the peninsula, were rapidly disappearing at the time of the investigation, mainly because of the ravages of wolves. The waters of the area, both salt and fresh, also abound in wildlife. Salmon, halibut, trout, and shellfish are especially abundant, and sea mammals, such as whales, dolphins, porpoises, seals, and sea lions are frequently seen. Land birds, although common, are small in number compared to the great numbers and varieties of sea birds. The most frequently seen land birds are the song sparrows, ravens, Alaskan longspurs, ptarmigans, hawks, and eagles. Ducks, geese, gulls, terns, puffins, murres, and cormorants abound along the coasts. 


\section{GEOLOGY}

\section{GENERAL FEATURES}

The general geologic features of the Frosty Peak area are shown on plate 79. The area is readily divisible into three general geologic units: a group of moderately deformed, probably middle to late Tertiary volcanic and marine sedimentary rocks that crop out along the Pacific coast; a series of younger, probably late Tertiary and early Quaternary volcanic rocks that make up the composite stratovolcanoes built up on the northern flanks of the older rocks; and the Pleistocene and Recent unconsolidated deposits that comprise the Bering Sea coastal lowlands and the lowlands adjacent to the larger bays. Frosty Peak volcano dominates the area; its history is virtually the history of the building and development of successive composite volcanic cones, their waning and partial destruction by eruption, collapse, and erosion; and finally, the building and development of the present Frosty Peak volcano summit cone within the caldera of the ancestral volcano.

\section{TERTIARY ROCKS}

Tertiary units of the area consist of both sedimentary and igneous rocks. The sedimentary rocks include marine graywacke, poorly consolidated marine sandstone and fine conglomerate, and volcanic sandstone and conglomerate. The igneous rocks are predominantly extrusive rocks of basaltic composition-tuffs, flows, breccias, and agglomerates-but some are of andesitic composition, and some are mafic and felsic intrusive rocks. In general, these igneous rocks appear to belong to the calc-alkalic circum-Pacific suite (Coats, 1952; Gates and others, 1954).

\section{BELKOFSKI TUFF}

A thick series of well-bedded tuffs and agglomerates and some interbedded flows, named the Belkofski tuff by Kennedy and Waldron $(1955$, p. 6), crop out principally east of Cold Bay and are believed to be the oldest rocks in the Frosty Peak area. The Belkofski tuff occurs along the Pacific coast from King Cove to Kaslokan Point, and although not observed, probably also underlies most of the mountainous area immediately surrounding Lenard Harbor. Only one isolated outcrop, too small to map, was observed west of Cold Bay. This outcrop is exposed for about 10 feet vertically and for less than 200 yards along the base of the south wall of the large valley that trends westward from Thinpoint Lagoon. Fragments and pebbles of tuff that lithologically resemble the Belkofski tuff occur in many beach and stream deposits. 
The Belkofski tuff is composed largely of fine- to coarse-grained lithic tuff, ranging from green to purple to gray. In many places the tuff has been reworked by water, so that the originally angular fragments are now subrounded to rounded, and the rocks may. be classed as volcanic sandstone and volcanic conglomerate (Wentworth and Williams, 1932, p. 50). The tuff is made up chiefly of a microcrystalline aggregate of feldspar microlites and chlorite, but includes crystals and angular fragments of oligoclase feldspar. Interbedded flows or sills of basalt and andesite are common and, because of their greater resistance to erosion, form benches on the steeper slopes in many places. Locally, tuff has been silicified and sericitized; introduced metallic minerals are not abundant, and the chief one is pyrite. The total thickness was not ascertained, but it is at least several thousand feet.

The age of the Belkofski tuff is believed to be middle Tertiary, but evidence for the age determination is not conclusive. The only pyroclastic deposits on the peninsula known to be of early Tertiary age are the "lower" beds of Palache's (1904, p. 74-77) Stepovak series. These rocks seem to occur only locally, however, and are not comparable to later pyroclastic deposits that occur extensively throughout the peninsula; and are assigned a post-Eocene age by Atwood (1911, p. 48-52), Smith and Baker (1924, p. 185-187), and Knappen (1929, p. 198-201). No fossils were found in Frosty Peak area, but many plant fossils were found in better exposures of the tuff in the Pavlof area (Kennedy and Waldron, 1955, p. 6). The principal fossils are silicified and carbonized plants and trunks of both deciduous and evergreen trees; in places, impressions of conifer needles also occur. Partly on the evidence of the fossil trees and partly by analogy with nearby areas, a post-Eocene and pre-Pleistocene age for the Belkofski tuff in the Pavlof area was indicated, and the rocks were tentatively assigned an age of late Tertiary (Kennedy and Waldron, 1955, p. 7), principally because younger sediments of known Tertiary age did not crop out in the area. Atwood (1911, p. 59-62), however, describes a sequence of pyroclastic deposits, intruded by dacite (?) and diorite porphyrite, that occur in the Herendeen Bay-Unga Island area to the east. He considered these volcanic rocks to be late Eocene to early Miocene in age because they overlie the Kenai formation (Eocene) and underlie the Unga formation (Miocene). The occurrence in the Frosty Peak area of younger Tertiary marine sedimentary rocks (Tachilni formation) suggests that the Belkofski tuff is most nearly correlative with Atwood's late Eocene or early Miocene volcanic rocks and that the most probable age for the Bellkofski tuff, therefore, is middle Tertiary rather than late Tertiary. 
TACHILNI FORMATION

The name Tachilni formation is here given to a sequence of predominantly marine sedimentary rocks that crop out discontinuously along the Pacific coast from the west side of Thinpoint Cove at least as far west as Cape Tachilni. Owing to hazardous landing conditions along the Pacific coast and to the difficult accessibility of the area, except by boat, these rocks were examined only cursorily in a few localities along the beach. Consequently, neither their extent inland nor the details of their stratigraphy are known. The formation contains a series of very dark brown to light-greenishgray fine- to coarse-grained fossiliferous sandstone, graywacke, grit and fine-grained conglomerate, and some black shale. Stratification and sorting differs and grades abruptly, both laterally and vertically. Crossbedding occurs in places. The material is mostly only semiconsolidated; locally near intrusive bodies, the rocks are well indurated.

Near Cape Tachilni, the type locality, more than 200 feet of poorly consolidated sedimentary rocks, rich in marine fossils, is well exposed in a small ravine. Here the beds dip gently northward and are unconformably overlain by lava flows. They include crossbedded coarse-grained gray to brown sandstone alternating with fine-grained conglomerate, pebbly sandstone, and some thin black shale. Some beds are cemented with iron oxides; others contain many concretionary masses. Locally, thin-bedded shale and sandstone are crumpled, contorted, and cut by many small faults; this suggests slumping during or shortly after deposition.

A typical sandstone in the vicinity of Thinpoint Cove consists of about 30-35 percent angular to subrounded quartz grains 10-15 percent euhedral feldspar grains, including some microcline, 5 percent pyroxene and amphibole grains, 30 percent angular to rounded fragments of volcanic rock, and 20 percent matrix mainly composed of a mixture of chlorite and some calcite, mica, and sericite. The rock may be classed as a medium-grained subgraywacke (Pettijohn, 1949, p. 255). It occurs in a sequence of light-greenish-gray sandstone that weathers to light brown and ranges in grain size from fine to coarse. These beds also contain pelecypods and many lenses and scattered pebbles of volcanic rock.

A typical fine-grained conglomerate or granule sandstone of this formation consists predominantly of well-rounded granule-sized fragments of altered volcanic rocks and pumice and contains a few scattered small grains of quartz. The matrix is composed of an intimate mixture of chlorite, calcite, serpentine, and an unidentified cryptocrystalline material which appears to be a mixture of clay 
minerals and chalcedony, but part of which may be devitrified ash. Pelecypods and gastropods occur in this unit.

The total thickness of the formation is not known, but at least several hundred feet of the material is exposed along the coast. The base of the formation was not seen.

In the eastern part of the area, the Tachilni formation is unconformably overlain by lava flows; westward, however, it appears to pass upward conformably into a basal sequence of nonfossiliferous volcanic sedimentary rocks succeeded by interbedded pyroclastic rocks and lava flows. Presumably all the overlying rocks are part of the Morzhovoi volcanics, but the true relation between these two formations in that area is not known.

Some collections of marine invertebrate fossils were made from rocks of the Tachilni formation, but unfortunately they were lost in transit. Fossils most common seen were echinoids, gastropods, and pelecypods, apparently shallow-water types similar to the presentday forms found on the beaches, and hence probably not too diagnostic, except to indicate that the rocks are not older than Tertiary in age. Some fragments of carbonaceous plant material also occur in parts of the formation, but none suitable for identification were obtained. The author believes that the formation is younger than the Belkofski tuff, but the contact between the two was not seen. Farther east on the peninsula, Atwood (1911) describes marine sedimentary rocks of both Eocene and Miocene ages, the Kenai and Unga formations, respectively, which are separated by a considerable thickness of volcanic rocks. The rocks of the Kenai formation are more deformed and better consolidated than those of the Unga formation; in addition, the Kenai formation has been intruded by silicic intrusive rocks, but the Unga formation has not. Lithologic, stratigraphic, and structural similarities that seem to exist between the Unga and Tachilni formations suggest that they may be correlative in time of deposition. Therefore, pending future paleontological determinations, the Tachilni formation is tentatively assigned to the late Tertiary.

The fauna and lithology of the rocks suggest that they were deposited in a shallow-water nearshore shelf environment on a slowly subsiding coast. The invertebrate fossils, although occurring throughout the formation, appear to be most concentrated in finegrained conglomerate, suggesting either rapid burial during times of more vigorous alluviation, or more likely, accumulations by wave action along interstream strandlines. Likely sources of the clastic material in the Tachilni formation are the volcanic sedimentary rocks of the Belkofski tuff and the related stocks of quartz diorite of the Frosty Peak area and of the Pavlof area to the east. 


\section{VOLCANIC ROCKS OF THINPOINT LAGOON}

Isolated knobs and hills of volcanic rocks of unknown age, which appear to be lithologically similar, occur in the vicinity of Thinpoint Lagoon. The material consists predominantly of basaltic lapilli tuffs and includes some basaltic lava flows and very coarse grained breccias and agglomerates. Some of the breccia and agglomerate fragments are as large as 20-30 feet in diameter; most fragments, however, are coarse lapilli, and range from 1 to 3 inches in diameter. The very coarse breccias and agglomerates are probably throat or vent breccia remnants of old volcanoes. Olive-drab colors, largely the result of oxidation and palagonitization, predominate in the rocks, but some included fragments are black. The lavas and pyroclastic fragments are predominantly porphyritic basalts with intersertal textures and are composed chiefly of tabular- and lath-shaped phenocrysts of labradorite in a matrix of brown glass and palagonite. Some of the rocks have a hyalopilitic texture, and the groundmass is composed of microcrystalline laths of feldspar interwoven with glass and grains of magnetite. Commonly, only a small amount of pyroxene is present, either augite or hypersthene, or both. Other minor constituents include magnetite, other iron oxides, zeolites, calcite, cristobalite, tridymite, and chlorites. Olivine, where present, is commonly replaced by iddingsite and magnetite.

The age and stratigraphic relationships of these volcanic rocks to other rocks in the area are not definitely known; they appear to be definitely older than the stratovolcanoes and possibly as old as the Belkofski tuff. They are arbitrarily assigned a Tertiary age.

\section{TERTIARY AND QUATERNARY ROCKS} MORZHOVOI VOLCANICS

The name Morzhovoi volcanics is here given to a sequence of lava flows and interbedded pyroclastic rocks, and some associated volcanic sedimentary rocks, that overlie the Belkofski tuff and Tachilni formation. This mass of volcanic rocks comprises the eroded remnants of an ancient large composite volcanic cone, here called Morzhovoi volcano, in the area south of Frosty Peak. The two Walrus Peaks and other higher peaks in the area are believed to be remnants of the caldera rim of this ancient volcano.

Volcanic sedimentary rocks constitute the base of the formation and crop out along the Pacific coast south and east of Reynolds Head, here designated as the type locality. These rocks consist of poorly consolidated dark sandy shale, sandstone, and fine- to coarse-grained conglomerate composed of subrounded to rounded fragments of volcanic debris. They are conformably overlain by interbedded lava flows, coarse agglomerates, and volcanic breccias. 
The lava flows of Morzhovoi volcano are light- to pinkish-gray porphyritic basalts; an intersertal texture is most common, but in some of the flows textures are intergranular or hyalopilitic. The principal phenocrysts are plagioclase (30-40 percent), augite (3-10 percent), hypersthene (2-15 percent), and olivine (0-5 percent). Accessory minerals are principally magnetite and apatite. Secondary or alteration products are magnetite, limonite, iddingsite, serpentine, chlorite, tridymite, cristobalite, biotite, antigorite, and zeolites. The plagioclase phenocrysts are mostly subhedral labradorite, but some are bytownite; they range in size from 0.1 to $3.0 \mathrm{~mm}$. The composition ranges from $A_{60}$ to $A n_{75}$ and averages about $A n_{63}$. Most of the feldspars are unaltered, but many have inclusions of glass, apatite, and unidentified cryptocrystalline materials; commonly they have progressive zoning and polysynthetic twinning. Hypersthene phenocrysts are euhedral to subhedral, weakly pleochroic, commonly unaltered, and range in size from 0.1 to $2.8 \mathrm{~mm}$. Augite phenocrysts are euhedral to subhedral, commonly twinned, unaltered, and range in size from 0.1 to $0.8 \mathrm{~mm}$. Olivine occurs in small amounts in nearly all the rocks examined. Where olivine is present, the hypersthene content is low; where olivine is absent, the hypersthene content is higher. Most of the olivine is subhedral and rarely larger than 0.2 $\mathrm{mm}$ in diameter; commonly it is altered to iddingsite along joints and fractures, and less commonly it is partly or completely replaced by serpentine. Magnetite pseudomorphs of hornblende were seen in a few of these rocks; generally they are associated with minor amounts of chlorite and limonite, and only rarely with biotite.

Most of the interbedded pyroclastic rocks of Morzhovoi volcano are coarse-grained agglomerates and breccias. In the field the rocks appeared to be composed of fragments of light- to pinkish-gray porphyritic lava, similar to the flows just described, set in a tuffaceous matrix. The rocks were not examined microscopically.

The Morzhovoi volcanics do not appear to have been deformed. The low dips observed are believed to be all primary or initial outward dips of a quaquaversal nature, which originated by eruption from either a central vent or from fissures on the flanks of the cone. The total thickness of the Morzhovoi volcanics is not known, but at least 3,000 feet of the formation is exposed.

The lack of fossils in the Morzhovoi volcanics precludes any precise determination of their age. The relative age, however, can be determined with some degree of confidence. Lithologically and mineralogically they are distinct from the older Belkofski tuff and Tachilni formation, and to a lesser degree from the rocks comprising the younger stratovolcanoes. The older rocks are better consolidated and 
more altered than the Morzhovoi volcanics. Olivine, which is common in the Morzhovoi volcanics, is a rare component of the postMorzhovoi volcanic rocks. Structural differences are not diagnostic because the amount of deformation of the older Tertiary formations in many places is no greater than the initial dips of the Morzhovoi volcanics. The Morzhovoi volcanics, although believed largely to postdate the deformation of the older rocks, may be in part contemporaneous with some of the deformation. If the older rocks are late Tertiary in age, as postulated, then the Morzhovoi volcanics cannot be older than latest Tertiary in age. Late Tertiary and early Quaternary (?) volcanism has been described in the western Aleutians by Simons and Mathewson (1955, p. 28-29) and by Coats (1956a, p. $50 ; 1956$ b, p. $72 ; 1956 \mathrm{c}$, p. 91 ), and farther east on the Alaska Peninsula by Atwood (1911, p. 69-71), and by Kennedy and Waldron (1955, p. 11).

By comparing the intensity and degree of glacial erosion of Morzhovoi volcano with that of Frosty Peak volcano, it is readily apparent that Morzhovoi volcano either is much older than Frosty Peak volcano, or that the latter has been active for a much longer span of time. Morzhovoi volcano has been deeply eroded into serrated peaks and knifelike ridges, separated by broad flat $U$-shaped valleys, some of which have completely breached what must have been the old caldera wall. Consequently, the original shape of the volcano has been almost completely destroyed, and all that can be seen now is the skeletal remains of what was once a major volcano. Frosty Peak volcano, in comparison, has been less severely eroded by glaciers, so that it retains much of its original symmetry. It is the author's opinion, therefore, that Morzhovoi volcano is not younger than middle Pleistocene in age.

BASALT FLOWS OF MOUNT ISIMEON

A sequence of olivine basalt flows makes up a low isolated mountain mass, 942 feet high, 3 miles west of the airfield. The mass occurs as an asymmetric island of rock with steep northeast slopes and gentle southwest slopes surrounded by glacial drift. Because of the glacialdrift cover, exposures are poor, but four separate flows could be seen in the steeper northeast side. All flows have an apparent gentle dip southwestward toward Frosty Peak. These lavas are light-gray porphyritic rocks with an intergranular texture. The principal phenocrysts are plagioclase (35-40 percent), olivine ( 5 percent), pyroxenes (10-15 percent), and amphibole ( 5 percent). Accessory minerals are magnetite, apatite, crystobalite, and zeolites. The plagioclase is euhedral labradorite with an average composition of about $\mathrm{An}_{68}$. The phenocrysts range in size from a few tenths of a millimeter to about $2 \mathrm{~mm}$ and are commonly zoned and polysynthetically 
twinned. The pyroxene phenocrysts consist of both euhedral and subhedral augite crystals as large as $1 \mathrm{~mm}$ and hypersthene crystals as large as $2 \mathrm{~mm}$; the hypersthene is only weakly pleochroic. The amphibole is brown basaltic hornblende that occurs as phenocrysts as large as $0.8 \mathrm{~mm}$. Invariably the hornblende is partly replaced by magnetite and chlorite, and the magnetite commonly forms dark corroded rims around the crystals of hornblende. The olivine phenocrysts are subhedral, unaltered, and as large as 0.5 millimeter in maximum diameter.

The extreme dissection and the composition of the lavas, which are similar to those of Morzhovoi volcano, suggest that the basalt flows of Mount Simeon were extruded sometime during late Tertiary to middle Quaternary time.

\section{INTRUSIVE ROCKS}

Intrusive rocks of the area include Tertiary stocks of quartz diorite, and Tertiary and Quaternary plugs, sills, and dikes of basalt and andesite. The two stocks in the mapped area are intruded into the Belkofski tuff: one is at the head of Lenard Harbor, and the other near the head of the large valley that trends westward from Thinpoint Lagoon. At Thinpoint Lagoon the stock is unconformably overlain by younger volcanic rocks. The stocks are made up of a medium to coarsely crystalline quartz diorite that contains about 5-10 percent quartz, 70-75 percent feldspar, and about 20 percent mafic minerals. Accessory minerals are apatite, biotite, and magnetite; the only alteration product is uralite. The quartz is anhedral and commonly forms granophyric intergrowths with orthoclase. Potassium feldspars are principally orthoclase and some microcline; plagioclase feldspars are principally andesine with an average composition of about $\mathbf{A n}_{48}$, and a range in composition of from about $\mathrm{An}_{30}$ to $\mathrm{An}_{60}$. The mafic minerals are largely augite and hypersthene; twinning is common in the augite but absent in hypersthene, and normally both are partly altered to uralite. The adjacent tuff beds have been locally sericitized, silicified, and bleached for a considerable distance from the stocks, so that the original composition of the rocks in these altered areas is difficult to determine.

Twin intrusive plugs of porphyritic hornblende andesite of an unknown age constitute Amagat Island. A landing was not feasible at Egg Island, but observed from a boat close inshore, it appeared to be a single plug similar to Amagat, and possibly contemporaneous with it in age. The Amagat Island plugs consist of approximately 25 percent andesine phenocrysts, 0.1 to $5.5 \mathrm{~mm}$ long, and 5 percent green hornblende euhedra, 0.1 to $4.0 \mathrm{~mm}$ long, in a microgranular groundmass of stubby, tabular feldspar crystals and some carbonate minerals. Most of the feldspar phenocrysts are strongly zoned and resorbed. The hornblende phenocrysts are strongly pleochroic but 
rarely twinned; some of them are rimmed by calcite and magnetite. Other minor accessory minerals are apatite, antigorite, chlorite, and limonite.

Several other plugs of a porphyritic dark-gray to black augite and olivine basalt intrude the Tertiary formations. At the margins of the plugs, the adjacent strata have been locally tilted and deformed. Numerous sills and dikes of dark-gray andesite and darkgray to black basalt also intrude the Tertiary formations, and some basalt dikes intrude the younger stratovolcanoes. Most of the dikes are small, ranging in thickness from 6 inches to 15 feet; only a few are more than 20 feet thick. As they can be traced for only short distances, they were not mapped.

\section{QUATERNARY ROCKS}

Quaternary rocks of the area include volcanic rocks of the composite cone of Frosty Peak volcano and the Pleistocene and Recent unconsolidated sediments of glacial, fluvial, marine, eolian, and volcanic origin.

\section{FROSTY PEAK VOLCANICS}

The dominant topographic and geologic feature in the area is the composite volcanic structure whose most prominent cone is Frosty Peak; the composite volcano is here called Frosty volcano. Although the earliest history of this volcano is obscured, activity presumably began from a single central vent somewhere near the present craters, and additional vents and fissures on its flanks probably contributed to its growth at various times. A shifting of the principal vent during the later stages of its development is indicated by the remnants of the two coalescing craters which now form the present summit caldera. Although explosive activity occurred at intervals throughout the growth of the main cone, it was subordinate to effusive activity. The explosions that did occur must have originated mainly from a magma at a low temperature, as most of the ejecta was blown out in a solid state and came to rest on the slopes as angular blocks in an ashy matrix. Because true scoria and rounded bombs are rare, the explosions were probably not of the Strombolian type of eruption, in which the ejecta would be sufficiently viscous to have their forms modified in flight.

The lava flows and pyroclastic rocks erupted from Frosty volcano; here named the Frosty Peak volcanics, are mostly augite basalts or hypersthene-augite basalts; a few are hornblende basalts. The type locality is Frosty Peak. The rocks are predominantly light gray, where unoxidized or unaltered, and are porphyritic. Most of the rocks have a felted or pilotaxitic texture; some have an intersertal texture; and only a few have an intergranular texture. The prin- 
cipal phenocrysts are plagioclase $(25-40$ percent), hypersthene (trace to 6 percent), and augite (3-8 percent); hornblende (0-8 percent) and olivine (0-2 percent) were seen in some thin sections.

The plagioclase phenocrysts are mostly subhedral labradorite, ranging in size from 0.1 to $3.5 \mathrm{~mm}$ and in composition from $\mathrm{An}_{80}$ to $\mathrm{An}_{65}$. Generally the crystals are euhedral and unaltered and rarely do they show any resorption; commonly, however, they are progressively zoned, and many of the crystals show inclusions, principally of glass and apatite. The hypersthene phenocrysts are euhedral or subhedral and weakly pleochroic and range in size from 0.2 to $1.6 \mathrm{~mm}$. In a few flows some of the hypersthene and augite crystals are intergrown; in others, augite occurs as thin reaction rims around some of the hypersthene crystals. The augite phenocrysts are euhedral or subhedral and commonly twinned and range in size from 0.3 to $1.0 \mathrm{~mm}$. Both green hornblende and basaltic hornblende occur in these rocks. The latter predominates, and nearly all the crystals are rimmed with secondary magnetite, or are partly to almost completely replaced with magnetite. Olivine occurs sporadically and rarely, generally as anhedral crystals altered to antigorite, iddingsite, and magnetite. Accessory minerals are magnetite, apatite, and pyroxene and feldspar in laths and microlites; also included is volcanic glass. The most common secondary or alteration products are palagonite or chlorophaeite, magnetite, and calcite; others include hematite, limonite, antigorite, Iddingsite, and zoisite. Tridymite, calcite; and zeolites occur as vesicle filling.

Separation and measurement of individual flows is impossible at most localities, but it is estimated that the individual flows average less than 40 feet in thickness, and in only a few places does the thickness of any one flow appear to exceed 100 feet. Columnar structures in the flows are rarely well developed, but platy or slabby jointing is well developed in some places. Most of the rocks have little or no flow structure, and inclusions are uncommon. Local unconformities; which separate agglomerate beds from overlying lava flows, were seen in the large valley on the west flank of the mountain. Here small valleys 10 to 30 feet deep were eroded in some of the softer pyroclastic material prior to burial by later flows.

The maximum diameter of the two coalescing summit craters, which together constitute the caldera of Frosty volcano, is approximately $31 / 2$ miles in a northerly direction. The southern crater, which is the largest, is now nearly filled by the younger volcanic rocks of Frosty Peak; the northern crater, and the remainder of the southern crater, are almost completely filled with ice. Because of intensive ice action, probably no part of the original crater walls now exists; 
nevertheless, the present walls show the effects of extensive fumarolic action, and the normally somber colors of the lavas give way to more colorful hues of yellow, buff, brown, and orange. Where the lavas and pyroclastic materials have been attacked by rising gases and solutions they have been reduced to soft, friable masses of a brown earthy material, or they have been bleached to white kaolinic masses with films of sulfur and other minerals, chiefly iron oxides, lining the joints and fracture planes.

The compound nature and the scalloped margin of the caldera are probably related to concentric fracturing and collapse of separate cones, or the caldera may have been determined, in part, by collapse of the roofs of two semidetached magma chambers. Scalloped margins of the Santorin caldera in Greece (Williams, 1941, p. 268) and the Aso caldera in Kyushu in Japan (Williams, 1941, p. 278) have been ascribed to such processes, although both of these calderas are much larger in diameter than the caldera of Frosty volcano.

North of Frosty Peak, a rounded pluglike nunatak projects a few tens of feet above the icefield. Gaping bergschrunds, which surrounded it, prevented a detailed examination of the rock mass; it appeared, however, to be similar in megascopic character to the Frosty Peak lavas. Because of its position, the mass has been mapped with the Frosty Peak volcanics, but it could have been formed later than the formation of the caldera and contemporaneously with the volcanic rocks of the summit cone.

The age of Frosty volcano is not known, but it is presumed to be not older than Pleistocene. The amount of erosion by glaciers on the flanks of the volcano indicates that the volcano was probably largely completed before late glacial (Wisconsin) time, although the preservation of the symmetry of the cone suggests that the cone is probably not older than middle Pleistocene. The age of the Frosty Peak volcanics is therefore considered to be Pleistocene.

Because a permanent icefield obscures the configuration of the surface of the floor of the caldera, the summit cone of Frosty Peak is the only recognizable feature formed by volcanic activity after the development of the caldera. That some minor fumarolic activity still persists in the caldera, however, is apparent from a very mild odor of sulfur dioxide noted by the author while crossing the caldera icefield. The fumes presumably came from the eastern wall of the caldera, which was not examined at the time because of inclement weather. The presence of fumarolic activity in the caldera, however, does not necessarily mean that any violent eruptive activity has occurred within the caldera recently.

Volcanic rocks of the summit cone.-The summit cone of Frosty Peak volcano is a fairly symmetrical composite volcanic cone built 
up mainly within the southern crater, but partly overlapping the western rim of the caldera of its ancestral cone. The cone is approximately $11 / 2$ miles in maximum basal diameter; perennial snow and ice mantle the slopes of the cone, and only relatively narrow, knifelike ridges project above the frozen cover. Instead of the usual bowl-shaped crater, the summit is a precipitous spinelike mass. The summit of the spine stands 1,000 feet or more above the caldera icefield at the base of the cone. The altitude of the summit is not definitely known. On plate 79 it is shown as approximately 6,700 feet; on other maps and charts the altitude is shown as 5,784 and 5,820 feet. The rocks of the cone are very similar to the lavas of the main volcano and consist of light-gray hypersthene and augite porphyritic basalts and minor amounts of pyroclastic material. Phenocrysts of labradorite and subordinate augite and hypersthene are the most conspicuous minerals. Magnetite and apatite are common accessory minerals. The groundmass consists of plagioclase laths, augite grains, magnetite dust and grains, and brown glass.

Because erosion by ice and frost action has been most intensive on the eastern and northern slopes, where it has produced sheer cliffs, the summit is accessible only from the western side. The spine and parts of the cone exposed above the glacier on the north flank consist of lavas altered by solfataric action, producing colorful hues of brown, red, purple, yellow, and orange. The rocks are characteristically banded, containing considerable whitish material, probably from kaolinization of the feldspars. One thin section of relatively fresh rock from the summit spine resembles other lavas of the cone, but it is much more glassy. Zoned and twinned labradorite and pyroxene phenocrysts occur in a fine-grained matrix of stubby plagioclase laths, magnetite and hematite dust, glass, and some tridymite or cristobalite. Magnetite and hematite, and in places limonite, rim the pyroxenes; resorption and intergrowths of orthopyroxenes and clinopyroxenes are common. The specimen differs from others examined in thin section, however, in that unaltered glass occurs both as central cores and as concentric bands included within the plagioclase phenocrysts; this suggests that the lava was subjected to repeated and abrupt changes in temperature or pressure during extrusion and solidification.

The age of the summit cone, Frosty Peak, is not definitely known; considering the amount of glacial erosion, it probably has not been active for several hundreds or perhaps thousand of years.

\section{GLACIAL DEPOSITS}

Evidence of glaciation is abundant throughout the area: in the highlands, erosional features predominate; in the lowland, deposi- 
tional features are largely dominant. Both till and stratified drift occur, but stratified drift in the form of glaciofluvial deposits greatly exceeds all others.

Only small patches of thin glacial drift occur in the mountainous areas or in the areas bordering the Pacific Ocean. Most of the Bering Sea coastal lowland and the lowlands encircling the larger bays, however, are mantled to an unknown depth by glacial drift. The drift extends well into some of the valleys and to the heads of some of those now occupied by active glaciers. Eskers and moraines form prominent local topographic features on the lowlands, but the dominant surface expression of the lowlands is that of a pitted outwash plain with innumerable low hills and depressions, which commonly contain lakes, swamps, or mud playas. This pitted outwash surface is in turn mantled by a dense vegetal cover of tundra, grasses, flowering ferns, shrubs, and thickets of alders and willows. Consequently, except in the bluffs along the shores, exposures are extremely poor, and a separation of the drift into individual units was not made.

Glaciofluvial deposits of sand and gravel predominate in the exposures afforded by the sea bluffs. Varved clays are exposed at the bases of the bluffs at a few localities. Capps (1934, p. 152) noted glaciolacustrine deposits on the west shores of Cold Bay during his reconnaissance of parts of the Alaska Peninsula. Thin beds of ash and lapilli, 2-5 inches thick, occur near the surface of the proglacial deposits in many places. Lateral and vertical gradations in the glacial sediments are rapid, and both foreset bedding and local unconformities occur commonly. Generally, the quantity, size, and angularity of included cobbles and boulders increases progressively from the coast to the mountain slopes, along with a similar increase in the size and angularity of the particles constituting the matrix.

Typical sections exposed in the beach cliffs are as follows:

Section on sea bluff near foot of dock at Cold Bay

8. Soil, silty, ashy ; capped by tundra and grass_.....

7. Ash, silty, poorly stratified._. 4

6. Sand, pumiceous, coarse; thin clay strata less than .5 in. thick

5. Lapilli, fine, light-tan; in thin beds alternating with fine black lapilli, and light-tan plastic clay; 6 in. of silty sand at base_..._.......... 1-1.5

4. Silt, sandy, brown

3. Sand, poorly sorted and poorly stratified

2. Gravel, sandy

1. Gravel, pebbly, sandy; base not exposed, lower $12 \mathrm{ft}$ covered with slopewash

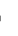
25 
6. Tundra and soil, dark-brown, ashy

5. Silt, sandy, dark-brown, massive

4. Sand and pebble gravel alternating in thin beds

3. Sand, stratified, coarse

2. Sand, silty, fine; with lenses of clay fragments

1. Clay, massive at top; grading into thinly laminated varved clay at base; dark layers $1 / 2$ in. thick, light layers 2-3 in. thick; base covered with slopewash

Total thickness of section

Nearly all fragments in the glacial deposits are volcanic rock types; the only erratics observed were pebbles of vein quartz or granitic rock. Both types are believed to be chiefly of local derivation, but their source is not definitely known. The granitic rocks are probably derived from local small intrusive bodies, such as the diorite stocks in Thinpoint Valley and at the head of Lenard Harbor; or they may be, in part, of accidental ejecta origin. Some small quartz stringers and veins are in mineralized zones bordering dioritic intrusive masses, and these could account for the erratic pebbles of vein quartz. Striated boulders are rare in the glacial drift; striated bedrock, however, is common.

The exact thickness of the glacial drift is unknown. Bedrock underlying drift in the lowland area is not exposed. During the Army's occupation of the present airport site during World War II approximately 35 wells were dug or drilled for water supply. Unfortunately, no logs of these wells were kept at the time, but several of the dug wells were deep (maximum of $71 \mathrm{ft}$ ), and many more were drilled to depths of 100 feet or more (maximum of $119 \mathrm{ft}$ ); none is believed to have penetrated bedrock below the drift.

The glacial drift mapped on the lowlands is probably nearly all late Pleistocene, presumably late $W$ isconsin in age (Capps, 1931, p. 4; Péwé, and others, 1953, p. 12). Although Atwood (1911, p. 87, 90) found no evidence of older glaciations in his reconnaissance of much of the southwestern part of the Alaska Peninsula, recent workers in many other parts of Alaska, including the northern part of the peninsula, have recognized the existence of several major glaciations Péwé and others, 1953, p. 12). Although Atwood (1911, p. 87, 90) occurs in the Frosty Peak area, but if so, it was not recognized in this study. The ice certainly melted from the lowlands prior to the last crustal movement, which elevated the peninsula at least 100 feet in respect to sea level, as indicated by elevated stream and marine terraces along the Pacific coast, by entrenched-stream channels in 
major valleys, both in alluvium and in bedrock, and by wave-cut cliffs and caves situated behind elevated beach ridges. Glaciers lingered in the mountains, however, long after ice had retreated from the lowlands; in the higher mountains, active glaciers are now contributing minor amounts of glacial drift to the upper reaches of the major valleys.

\section{RECENT DHPOSITS}

\section{ASH AND IAPIIII}

Thin layers of ash and lapilli, 2-5 inches thick, are widespread in the area both overlying the glacial drift and within the upper part of the drift. The material is generally coarse and falls in the upper and lower limits, respectively, of ash and lapilli. The material is commonly black and cindery or scoriaceous and includes some thin interbedded layers of pale-colored plastic, clayey very fine ash. The ash beds are overlain by a mantle, from 1 to 3 feet thick, consisting of a fairly homogeneous mixture of volcanic ash, silt, fine sand and plant remains, presumably mostly eolian in origin. Soil tests by the U.S. Army Corps of Engineers, Seattle District, Seattle, Wash., for the Civil Aeronautics Administration, reveal the material to consist of approximately 50 percent clay mineral aggregates, 20 percent volcanic ash, 10 percent quartz grains, 10 percent feldspar grains, and 10 percent organic material. The clay aggregates were probably formed from weathering of the feldspars and volcanic ash. Prevailing wind directions are such that only rarely could ash from Pavlof volcano or any of its satellites ever reach the western shores of Cold Bay. Most ash in the Cold Bay area was presumably derived from the volcanoes of Frosty Peak, or Amak Island to the north, which has been active more recently than Frosty Peak cone (Coats, 1950).

\section{SAND DUNES}

Large areas of well-sorted sand occur in dunes along the coasts; on the geologic map ( $p l .79$ ) only a few of the larger dune areas are shown. Onshore winds from the Bering Sea have blown sand from the wide beaches to form large foredunes which parallel the shoreline and cap the low bluffs. Large sand dunes parallel the shoreline and cap older beach ridges along the Pacific coast and in some of the larger bays, especially in the vicinity of the mouths of large streams and at the heads of shallow bays where abundant source material is available. Most of the dunes are fixed at present by a rank growth of beach grass; this suggests that most were formed during a much drier or colder climate than exists today. 


\section{ALLOVIUM}

Recent alluvial deposits of unconsolidated gravel, sand, silt, and clay mantle the valley bottoms and flood plains. Terraces are rare, mostly because the overdeepening and widening of the valleys by glaciers has promoted the accumulation rather than removal of alluvium since glaciers filled the valleys. Detritus, contributed by steep, swift tributaries and by talus and soil creep, overloads the main streams, which then form braided channels on the flat valley floors of the streams draining into the Bering Sea and some of the larger bays. Streams draining into the Pacific Ocean, however, have been able to transport this detritus because they have steeper gradients and shorter courses. Consequently some valleys contain only a thin alluvial cover, 10 feet or less in thickness, and some of the streams are now incising their channels into bedrock.

Coarse gravel and sand predominate in the alluvium, but large amounts of silt and clay are mixed with the coarser fractions in the lower stretches of the larger streams; this fine material is contributed as rock flour from active glaciers and permanent icefields. In some of the larger valleys which still retain active cirque glaciers at their heads, outwash as it moves downstream is gradually diluted by nonglacial alluvium until eventually the outwash is lost in this alluvium. The distinction between glacial outwash and valley alluvium on the geologic map (pl. 79), therefore, is arbitrarily shown in most places.

\section{BEACH DEPOSITS}

A variety of beach deposits occur in the area, ranging from lagoonal muck and muds to coarse cobble and boulder deposits in beaches, spits, and bars. On the Pacific coast the Tertiary sedimentary and volcanic rocks and the glacial drift are being eroded rapidly by the vigorous action of waves and currents. The sand and gravel thus produced is deposited nearby as spits and bars, or as broad sandy beaches in the more sheltered heads of bays and coves. Spits at the mouths of lagoons are commonly composed of cobbles, indicating strong longshore currents; and prominent cobble spits nearly enclose Littlejohn Lagoon in Morzhovoi Bay and the two lagoons on the west shores of Cold Bay opposite Kaslakan Point. Large sand spits similarly almost enclose Thinpoint Lagoon and also produce the large lagoons at the heads of Morzhovoi and Cold Bays. Successive beach ridges are conspicuous behind the sand spits on the seaward side of Thinpoint Lagoon. The beach ridges are composed of either sand or gravel, whereas the swales commonly contain lakes or are swampy and filled with muck. Black sand, consisting chiefly of magnetite and pyroxenes, occurs locally along some of the beaches. Boulders, principally erratics derived from the glacial 
drift, occur in many places along the beach and offshore. Most of these boulders are small, but some exceed 6 feet in diameter and are a hazard to small boats.

On the Bering Sea coast, where no bedrock is exposed to direct wave action, the erosion of the low bluffs of glacial drift and alluvium has produced extensive sand beaches. Large offshore sandbars, from a few feet to several tens of feet high, have been built upon the gently shelving floor of the Bering Sea. In places these sandbars are as much as 3 miles from the mainland shore.

\section{COILUVIUM}

Unconsolidated talus and other waste rock, ranging from coarse blocky lava rubble to fine sand and silt, mantles the lower slopes of the valley walls and beach cliffs. Composition of the material mainly reflects the type or types of rocks that crop out in the walls of the cliffs and valleys. In many places some finer eolian material included in these deposits is principally intermingled ash and silt. Most of the valley colluvium is relatively stable, except at those points where the stream is actively cutting into a slope. However, colluvium along the coast tends to be less stable because of continued wave erosion, unless the slopes are protected by beach ridges.

\section{STRUCTURE}

The inferred structure of the area is shown in the geologic cross section shown on plate 79. The major structural feature is the north limb of a broad anticline that forms the Aleutian Range farther east on the Alaska Peninsula. Superimposed on the eroded remnants and northern flank of this anticline are the great masses of late Tertiary and Quaternary stratovolcanoes with their individually developed structures. The oldest rocks in the area, the Tertiary marine and volcanic sedimentary rocks, in general, have northerly and northwesterly dips of $10^{\circ}-20^{\circ}$, locally as steep as $35^{\circ}$; dips as steep as $75^{\circ}-80^{\circ}$ were noted only in the vicinity of intrusive masses. Although these older rocks are faulted to some extent, there appears to be very little contortion of individual beds. Only at one locality, where thinbedded shale, sandstone, and lenses of fine conglomerate were cut by many faults of small displacement, was crumpling and contortion of the shale beds observed. The abrupt termination of the Belkofski tuff at the eastern shores of Cold Bay suggests the existence of a major transverse fault in the vicinity of the bay, which probably accounts for the existence of the bay. No major linear faults were recognized in the younger volcanic rocks, but it is inferred that arcuate faults border the calderas. 


\section{GEOMORPHOLOGY}

Before the geomorphology of the Frosty Peak area can be completely understood, much more detailed local and regional studies of the western extremity of the Alaska Peninsula are needed. It is proposed here to point out some of the events that have occurred in the evolution of the major topographic features of the area, and to present some of the problems that must await future studies.

A major lowland of varied width extends northwest from the mountain slopes to the shores of Bristol Bay. It is nearly continuous for the entire length of the peninsula, with a greatest width of about 25 miles. This tundra-covered lowland plain rises gradually from the Bering. Sea to intersect sharply with the mountain slopes at an altitude of about 200 feet; in some places the plain merges imperceptibly with the mountain slopes. The surface of this plain is now underlain to an unknown depth with glacial drift and alluvium. With the exception of a few isolated volcanic knobs projecting above the plain, bedrock was not observed anywhere on the lowland in the Frosty Peak or Pavlof areas. Exposures are very poor, however, and much of the lowland was not examined in detail, so that bedrock may be at or very near the surface in several places. The total areal extent of this plain, which certainly is much greater than that now exposed, is difficult to determine because of the lack of detailed hydrographic surveys of the adjoining Bering Sea.

How the plain was formed is not known, but it is presumed to be a broad coastal plain, formed before Pleistocene time, apparently the result of subaerial and marine erosion of a gradually rising coast which was subsequently modified by glacial action and the deposition of drift, and by changes of sea level during the Pleistocene. That part of the plain now exposed is almost entirely constructional and has been formed by the deposition of till and proglacial outwash which, in part, have been reworked and redeposited by streams and waves.

The age of this coastal plain is similarly unknown, but it may have been in the process of forming since middle Tertiary time, comparable to major erosion surfaces noted farther west (Gates and others, 1954, p. 447; Gates and others, 1956, p. 130; and Coats, 1956c; p. 91).

Little else is known of the earlier erosional history of the area because of the subsequent modification by intensive glaciation throughout the Pleistocene. At some time, and perhaps several times during the Pleistocene epoch, the mountainous areas accumulated extensive icefields. Valley glaciers from these icefields coalesced on the Bering Sea lowland to form large piedmont glaciers several hundreds of 
feet thick. Valley glaciers that discharged southward, however, were much shorter and apparently calved off directly into the Pacific Ocean without forming piedmont glaciers.

A local icecap may have existed in the area during glacial times. Although the present-day climate is cool and comparatively mild and the precipitation is relatively low, this climate together with the topography are such that a much greater accumulation of snow and ice could very easily occur with any prolonged lowering of temperatures. If it is assumed, as has just been suggested, that the Bering Sea surface was completely frozen during glacial times, then the air overlying the frozen surface of the Bering Sea could take on continental characteristics, and much lower temperatures would occur than under present conditions. Then, if the Pacific Ocean remained as an open body of water, the peninsula would be the confluence of very cold and dry northern continental air masses with moister and warmer maritime air masses-an ideal situation for large accumulations of snow and ice. Also, with progressively lowered normal temperatures, a perennially frozen Bering Sea would tend to produce even lower temperatures than normal, thus the persistence of snow would be increased throughout the summer months. The volume of ice produced from both increased snowfall and reduced melting might very easily grow to local ice-sheet proportions.

Because of the comparative warmth of the north Pacific Ocean, it seems unlikely that much sea ice developed along the Pacific coast, even during the glacial epochs. Because of the comparative coldness of the Bering Sea, however, it seems probable that sea ice very likely completely filled the Bering Sea during those parts of glacial times when sea level was high. During the winter of 1955-56, Cold Bay froze over for the first time on record, forming an ice layer about 4 inches thick and indicating that the Bering Sea surface to the northward was also completely ice covered (U.S. Dept. Commerce, 1956). Therefore it seems reasonable to expect that during times of glaciation, which were also times of prolonged minimum temperatures, the Bering Sea, and probably many of the smaller bays, were solidly packed with sea ice. Flint (1947, p. 223) arrived at a similar conclusion concerning the conditions that probably existed during glacial episodes in the Bering Sea and north Pacific Ocean.

Eustatic changes in sea level must have occurred in the area both during and after Pleistocene time, but to what extent is not known. The latest change in the Frosty Peak area has been an elevation of the land relative to sea level of a maximum of about 100 feet. Evidences of this change, however, were not studied in detail. A maximum sea-level reduction of about 45 to 150 meters (about 150-500 ft) 
probably occurred during the most extensive glaciation (Trumbull and others, 1958, p. 10). A lowering of sea level of this magnitude would expose nearly all of the Bering Sea shelf. Buffington and others (1950), believed that a rather continuous slope break at about 85 fathoms (510 ft) on this conspicuously flat shelf marked an old shoreline cut at a time of lowered sea level. How much of this depth can be attributed to an overall lowering of sea level and how much to crustal deformation is not known. Barth $(1956$, p. 154) believed that the Pribilof area in the Bering Sea was subject to large vertical crustal movements during the Pleistocene. His evidence, however, is based on the singular belief that the erosion surface developed on the basement peridotite could be due only to normal ice erosion. It seems more likely that the erosion surface was actually formed before Pleistocene time by wave action and that the evidence for glacial erosion is superimposed on a preexisting wave-cut platform. However, the erosion surface may have been formed principally by pack ice, as were the "strand flats" in the Frobisher Bay area on Baffin Island, Canada (Wengerd, 1951, p. 631). Either of these possibilities precludes the necessity for large crustal movement in the area.

\section{GEOLOGIC HISTORY}

The geologic history of the Frosty Peak area records recurrent and prolonged periods of volcanism separated by periods of relative quiescence. The latter are characterized by weathering, erosion, and normal stream alluviation and marine deposition.

The earliest event that can be inferred from the visible geologic records is a relatively long period of explosive volcanism, presumably in middle Tertiary time, when the beds of Belkofski tuff accumulated to a thickness of several thousand feet. Locally, the eruptive materials were extensively reworked by streams, and volcanic sands and gravels were deposited in lowland areas. Active volcanism was interrupted periodically, and forests of conifers flourished, only to be subsequently destroyed by burial from renewed volcanic activity. Later, volcanism ceased and a period of orogeny ensued, during which time the beds of the Belkofski tuff were intruded and altered by diorite.

Later in Tertiary time, when the land masses had been lowered by erosion, sea level fluctuated and sandstone, graywacke, fine conglomerate, and some shale-the Tachilni formation-accumulated on the bottoms of the shallow seas of the Pacific Ocean and the adjoining low-lying landmasses. These sedimentary processes were then interrupted, presumably near the close of Tertiary time, and the Tachilni formation and older rocks were compressed into gentle folds, and faulted. During this deformation, igneous activity was renewed, 
and basalt and andesite were intruded along zones of weakness developed in these older rocks.

Volcanism was again resumed in very late Tertiary or in early Quaternary time, and the large stratovolcano of Morzhovoi was built on the older Tertiary sediments and volcanic rocks, probably along rifts that developed in the older rocks; the basalt flows of Mount Simeon were also probably extruded at this time. At first the eruptions of Morzhovoi volcano must have been mostly explosive, as the initial products are predominantly pyroclastic and volcanic sedimentary rocks. Later, however, quiet flows of basaltic lava predominated. Formation of the summit caldera indicates that late in the history of this volcano active volcanism culminated in a series of eruptions, probably of gas-rich magma. The initial explosions were probably weak; later, however, the size and volume of ejecta increased until the energy had spent itself and the magma chamber had been depleted. When the magma chamber became exhausted, or nearly so, the crater walls began to collapse, until the entire summit of the cone had collapsed to form a large caldera, similar to the formation of other large calderas, such as Krakatoa, Santorin, and Crater Lake (Williams, 1941, 1942). Apparently after the collapse, in early or middle Pleistocene time, the volcano became inactive. Subsequent erosion by streams, glaciers, and frost action has removed much of the original volcano.

Later in the Pleistocene, while Morzhovoi volcano was still being dissected, volcanism was again renewed in Frosty volcano to the north. Whether this renewed activity stemmed wholly from an entirely new vent, or whether it represents renewed activity of a parasitic cone on the north flanks of the older volcano is not known. Late in the history of this volcano, active volcanism also culminated in a series of eruptions similar to that postulated for Morzhovoi volcano, and the summit of the cone collapsed to form a small compound caldera.

Late in Pleistocene time, after another period of quiescence, volcanism was again renewed-this time in the southern crater of the Frosty caldera-and the composite summit cone of Frosty Peak was built. After volcanism ceased, probably in late Pleistocene or Recent time, erosion by wind, waves, ice, and water greatly modified these volcanoes and their surrounding lowlands.

Some eustatic changes of sea level have occurred in the Frosty Peak area, probably both during and since the Pleistocene. The most recent change is a relative lowering of sea level, recorded by elevated stream and marine terraces near the Pacific coast, by entrenchedstream channels in major valleys, both in alluvium and in bedrock, and by wave-cut cliffs and caves behind elevated beach ridges. 


\section{REFERENCES CITED}

Atwood, W. W., 1911, Geology and mineral resources of parts of the Alaska Peninsula : U.S. Geol. Survey Bull. 467, 137 p.

Baker, Marcus, 1906, Geographic dictionary of Alaska: U.S. Geol. Survey Bull. 299 (2d ed.), $690 \mathrm{p}$.

Barth, T. F. W., 1956, Geology and petrology of the Pribilof Islands, Alaska: U.S. Geol. Survey Bull. 1028-F; p. 101-160.

Buffington, E. C., Carsola, A. J., and Dietz, R. S., 1950, Oceanographic cruise to the Bering and Chukchi Seas, summer 1949: Navy Electronics Lab. Rept. 204 , pt. 1, Sea floor studies.

Capps, S. R., 1931, Glaciation in Alaska: U.S. Geol. Survey Prof. Paper 170-A, p. 1-8.

- 1934, Notes on the geology of the Alaska Peninsula and Aleutian Islands: U.S. Geol. Survey Bull. 857-D, p. 141-153.

Coats, R. R., 1950. Volcanic activity in the Aleutian Arc: U.S. Geol. Survey Bull. 974-B, p. 35-49.

1952, Magmatic differentiation in Tertiary and Quaternary volcanic rocks from Adak and Kanaga Islands, Aleutian Islands, Alaska : Geol. Soc. America Bull., v. 63, p. 485-514.

- 1956a, Geology of northern Adak Island, Alaska: U.S. Geol. Survey Bull. 1028-C, p. 45-67.

- 1956b, Geology of northern Kanaga Island, Alaska: U.S. Geol. Surver Bull. 1028-D, p. 69-81.

1956c, Reconnaissance geology of some western Aleutian Islands, Alaska : U.S. Geol. Survey Bull. 1028-E, p. 83-100.

Collins, H. B., Jr., Clark, A. H., and Walker, E. H., 1945, The Aleutian Islands : Their people and natural history: Washington, Smithsonian Institution, War Background Studies 21.

Dall, W. H., 1896, Report on coal and lignite of Alaska : U.S. Geol. Survey 17th Ann. Rept., pt. 1, p. 763-875.

Flint, R. F., 1947, Glacial geology and the Pleistocene epoch: New York, John Wiley and Sons, $589 \mathrm{p}$.

Gates, Olcott, Fraser, G. D., and Snyder, G. L., 1954, Preliminary report on the geology of the Aleutian Islands: Science, v. 119, no. 3092, p. 446-447.

Gates, Olcott, Fraser, G. D., Snyder, G. L., and Gibson, William, 1956, Interpretation of the configuration of the Aleutian Ridge: Geol. Soc. America Bull., v. 67, p. 127-146.

Grewingk, Constantin, 1850, Beitrag zur Kenntniss der orographischen und geognostischen Beschaffenheit der Nordwest Kuste Amerikas, mit den anliegenden Inseln : Russ. K. min. Gesell. Verh., St. Petersburg, 1848-49, p. $76-342$.

Hubbard, B. R., 1935, Cradle of the storms: New York, Dodd, Mead, and Co., $285 \mathrm{p}$.

Jaggar, T. A., 1929, Mapping the home of the great brown bear: Natl. Geog. Mag., v. 55, p. 109-134.

- 1945, Volcanoes declare war; logistics and strategy of Pacific volcano science: Honolulu, Hawaii, Paradise of the Pacific, Ltd., $166 \mathrm{p}$.

Kennedy, G. C., and Waldron, H. H., 1955, Geology of Pavlof Volcano and vicinity, Alaska : U.S. Geol. Survey Bull. 1028-A, p. 1-19.

Knappen, R. S., 1929, Geology and mineral resources of the Aniakchak district, Alaska : U.S. Geol. Survey Bull. 797, p. 161-227. 
Palache, Charles, 1904, Geology about Chichagof Cove, Stepovak Bay; with notes on Popof and Unga Islands [Alaska]: Harriman Alaska Expedition, จ. 4, p. 69-88.

Pettijohn, F. J., 1949, Sedimentary rocks: New York, Harper and Brothers, $526 \mathrm{p}$.

Péwé, T. L., and others, 1953, Multiple glaciation in Alaska, a progress report: U.S. Geol. Survey Circ. 289, 13 p.

Simons, F. S., and Mathewson, D. E., 1955, Geology of Great Sitkin Island, Alaska : U.S. Geol. Survey Bull. 1028-B, p. 21-43.

Smith, W. R., and Baker, A. A., 1924, The Cold Bay-Chignik district, Alaska : U.S. Geol. Survey Bull. 755, p.151-222.

Trumbull, James, and others, 1958, An introduction to the geology and mineral resources of the continental shelves of the Americas: U.S. Geol. Survey Bull. 1067, $92 \mathrm{p}$.

U.S. Dept. of Commerce, Weather Bureau, 1956, Local climatological data with comparative data, 1956, Cold Bay, Alaska.

Wengerd, S. A., 1951, Elevated strandlines of Frobisher Bay, Baffin Island, Canadian Arctic : Geol. Rev., v. 41, p. 622-637.

Wentworth, C. K., and Williams, Howel, 1932, The classification and terminology of the pyroclastic rocks : Natl. Research Council Bull. 89, Rept. Comm. Sedimentation 1930-32, p. 19-53.

Williams, Howel, 1941, Calderas and their origin: California Univ. Pub., Dept. Geol. Sci. Bull., v. 25, no. 6, p. 239-346.

1942, The geology of Crater Lake National Park, Oregon, with a reconnaissance of the Cascade Range southward to Mount Shasta: Carnegie Inst. Washington Pub. 540, 162 p. 


\section{INDEX}

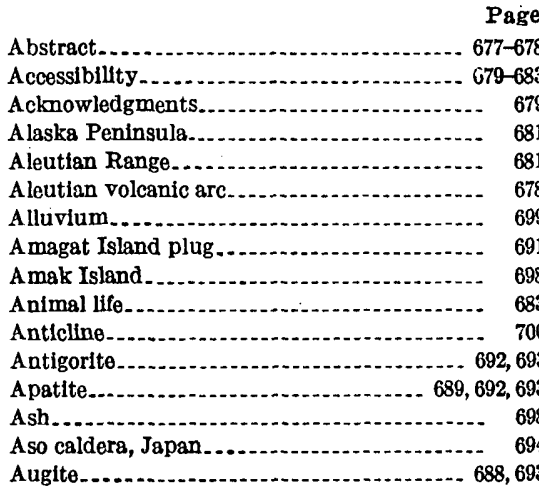

Barabaras (native Aleut sod huts).

Basalt flows $690-691,692,693$

Beach deposits

Bergschrunds. . 694

Bering Sea lowland............................ 682

Calcite.................................. 688,692,693

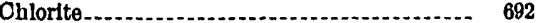

Chiorophaelte............................. 693

Climate..................................... 682-683

Cold Bay Airport............................. 681

Colluvium................................ 700

Cristobalite............................... 688, 689

Dikes.............................................. 692

Dralnage..................................... 681-682

Echinolds....................................... 687

Egg Island plug............................. 691

Erosion................................. 694, 700, 703

Erratics......................................... 697

Eustatic changes in sea level............ 702-703, 704

Fieldwork

Fossils......................................... 685, 687

Frosty Peak volcanics....................... 692-695

Gastropods.................................. 687

Geography......................... 670-683

Geologic history ........................... 703-704

Geomorphology ...................... 701-703

Glacial deposits............................. 695-698

Glacial drift_....

Glaciers................................ 698,699, 701

Hematite ...................................... 693

History, geologic........................... 703-704

Hornblende................................ 693

Hyperstbene.
Iddingsite.............................. 688, 689, 693

Introduction................................ 678

Investlgations, previous. . .................. 678-679

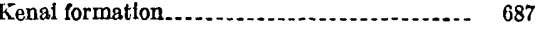

Labradorite............................... 688, 689

Lapilll_........................................ 698

Lavas. . .............................. 688, 689, 690, 694

Lenard Harbor................................ $\quad 684$

Limonite. ..................................... 692

Littlejohn Lagoon

Location................................... 670-681

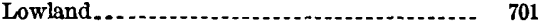

Magnetite............................ 688, 689, 682, 693

Morzhovol volcano.................... 688, 689, 690, 704

Mount Simeon, basalt flows of ............. 690-691

Nunatak........................................ 694

Olivine................................... 688, 689, 693

Palagonite.......................................... 693

Pavlof volcano ........ 679

Pelecypods.................................... 686, 687

Phenocrysts..................... 689, 690, 691, 693,695

Plugs_......................................... 691-692

Precipitation.................................. 682

Pumice............................................. 686

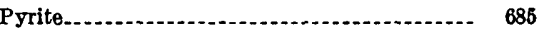

Pyroxene.......................................... 688

Quartz............................................... 686

Quartz diorite..................................... 691

Quaternary rocks............................... 692-700

Recent deposits... . . . .

References cited......... 705-706

Reynolds Head.............................. 688

Sand dunes.............................................. 698

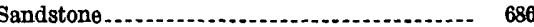

Santorin caldera, Greece...................... 694

Sills............................................ 692

Soll, tests of

Solfataric action................................. 695

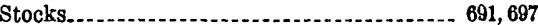

Storms, in report ares......................... 682

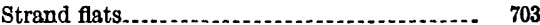

Stratovolcanoes................................. 692, 700, 704

Streams............................................... 699

Structure

Tachilni formation............................... 686-687

Tertiary rocks................................. 684-688

Tertiary and Quaternary rocks. ........... 6\$8-692

Thinpoint Lagoon, volcanic rocks of........ 688, 691 
Page $\quad$ Page

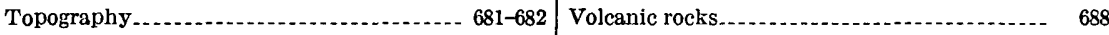

Transportation facilities, in report area....... 681 Volcanoes, potential danger to civil and mili-

Tridymite............................... 688, 689, 693

Tundra plants.

tary installations from

Williwaws......................................... 683

Unga formation

Uralite.

Vegetation. 